\title{
PERSEPSI PERAWAT DAN DOKTER TERHADAP PENERAPAN BUDAYA KESELAMATAN PASIEN DI RUMAH SAKIT ADVENT BANDAR LAMPUNG
}

\author{
PERCEPTION NURSES AND DOCTORS ON THE APPLICATION OF PATIENT \\ SAFETY CULTURE IN BANDAR LAMPUNG ADVENTIST HOSPITAL
}

\author{
Ernawaty Siagian \\ Fakultas IImu Keperawatan, Universitas Advent Indonesia \\ Email: ernawatysiagian74@yahoo.com
}

\begin{abstract}
ABSTRAK
Pendahuluan: Budaya keselamatan pasien dalam pelayanan rumah sakit adalah hal yang sangat mendasar. Permasalahan dalam budaya keselamatan pasien tercermin dari masih tingginya angka insiden keselamatan pasien baik secara global maupun nasional. Jumlah insiden keselamatan pasien di Rumah Sakit Advent Bandar Lampung yang dilaporkan tidak terlalu banyak. Namun berdasarkan hasil wawancara diketahui bahwa masih banyak insiden yang tidak dilaporkan oleh karena pekerja merasa enggan dan takut mendapat konsekuensi. Tujuan: Penelitian ini bertujuan untuk meningkatkan penerapan budaya keselamatan. Metode: Penelitian descriptive comparative cross sectional design tentang persepsi perawat dan dokter dilakukan kepada 130 responden dengan menggunakan instrument Hospital Survey of Patient Safety Culture (HSOPSC) yang terdiri dari 12 dimensi. Pengukuran persepsi terhadap masing-masing dimensi dilakukan untuk mengetahui dimensi mana yang masih perlu ditingkatkan. Uji statistic mann Whitney digunakan untuk mengetahui apakah terdapat perbedaan persepsi antara perawat dan dokter, antara staf pelaksana dan supervisor. Hasil: Hasil penelitian ini menunjukkan bahwa persepsi perawat terhadap 12 dimensi mempunyai nilai rata-rata $62.3 \%$. Ada 9 dimensi yang perlu ditingkatkan yaitu harapan dan tindakan manajer dalam meningkatkan keselamatan pasien (28.9\%); Respon tidak menghukum (39.0\%); Komunikasi terbuka (52.3\%); Kerjasama tim antar unit (55.0\%); Umpan balik dan komunikasi tentang kesalahan (60.9\%); Staffing (63.5\%); Dukungan manajemen rumah sakit terhadap program keselamatan pasien (63.6\%); Persepsi tentang keselamatan pasien secara menyeluruh $(65.0 \%)$ dan frekuensi pelaporan insiden $(73.9 \%)$. Sementara pada profesi dokter mempunyai nilai rata-rata $60.1 \%$ dimana 11 dimensi masih perlu ditingkatkan, yaitu: harapan dan tindakan manajer dalam meningkatkan keselamatan pasien (27.8\%); respon tidak menghukum (44.4\%); frekuensi pelaporan insiden (48.2\%); persepsi tentang keselamatan pasien secara menyeluruh $(59.0 \%)$; komunikasi terbuka (59.2\%); overran dan transisi $(61.1 \%)$; kerjasama tim antar unit (61.1\%); staffing (63.0\%); umpan balik dan komunikasi $(66.7 \%)$; pembelajaran organisasi serta perbaikan secara berkelanjutan $(70.4 \%)$ dan dukungan manajemen rumah sakit terhadap program keselamatan pasien (70.4\%). Diskusi: Kesimpulan dari penelotian ini adalah bahwa tidak terdapat perbedaan yang signifikan antara persepsi perawat dengan dokter, antara staf pelaksana dengan supervisor.
\end{abstract}

Kata Kunci: Budaya keselamatan pasien, perawat, dokter, persepsi, HSOPSC

\section{ABSTRACT}

Introduction: Patient safety culture in the hospital setting is very basic stuff. Problems in patient safety culture is reflected in the high number of patient safety incidents both globally and nationally. Number of patient safety incidents in Bandar lampung Hospital reported not too much, but based on interviews it is known that many incidents are not reported because workers are reluctant and fear of the consequences. Purpose: The purpose of this research is to increase the awareness of safety. Method: Comparative cross-sectional descriptive study on the perception of nurses and doctors performed to 130 respondens using instruments HSOPSC consisting of 12 dimensions. Measured perceptions of each dimensions are performed to determine the dimensions which need to be improved. Mann Whitney statistical test used to determine whether there are
JURNAL

SKOLASTIK KEPERAWATAN

Vol, 4, No. 1 Juli - Desember 2017

ISSN: 2443 - 0935 E-ISSN 2443 - 1699 
differences in perception between nurses and doctors, between staffs and supervisors. Results: These results indicate that the perception of nurses on 12 dimensions have an average value of $62.3 \%$. There are nine dimensions that need to be improved, such as supervisor/manager expectations and actions promoting patient safety (28.9\%); nonpunitive response to errors (39.0\%); open communication (52.3\%); team works across units (55.0\%); feedback and communication about error (60.9\%); Staffing (63.5\%); management support for patient safety (63.6\%); overall perceptions of patient safety (65.0\%) and frequency of events reported (73.9\%). While the medical profession has an average value of $60.1 \%$ of which 11dimensions still needs to be improved, that the supervisor/manager expectations and actions promoting patient safety (27.8\%); non punitive response to errors (44.4\%); frequency of events reported (48.2\%); overall perception of patient safety (59.0\%); open communication (59.2\%); handsoff and transition (61.1\%); team works across units (61.1\%); staffing (63.0\%); feedback and communication about error (66.7\%); organizational learning and continual improvement (70.4\%) and management support for patient safety (70.4\%). Discussion: Concusion of this study showed no significant differences in perception between nurses and doctors, between staff and supervisor.

Keywords: patient safety culture, nurses, doctors, perception, HSOPSC

\section{PENDAHULUAN}

Dalam Undang Undang Republik Indonesia no. 44 tahun 2009. Tentang Rumah sakit pasal 13 butir 2 menyatakan bahwa setiap tenaga kesehatan yang bekerja di rumah sakit harus bekerja sesuai dengan standar profesi, standar pelayanan rumah sakit, standar prosedur operasional yang berlaku, etika profesi, menghormati hak pasien dan mengutamakan keselamatan pasien. Rumah sakit mempunyai kewajiban untuk memberikan pelayanan kesehatan yang aman, bermutu, antidiskriminasi dan efektif dengan mengutamakan kepentingan pasien sesuai dengan standar pelayanan rumah sakit (pasal 29, butir 1b). Setiap pasien berhak memperoleh layanan yang efektif dan efisien sehingga pasien terhindar dari kerugian fisik dan materi, memperoleh keamanan dan keselamatan dirinya selama dalam perawatan di rumah sakit (pasal 32 e dan n). Rumah sakit wajib menerapkan standar keselamatan pasien yang dilaksanankan melalui pelaporan insiden, menganalisa dan menetapkan pemecahan masalah dalam rangka menurunkan anka kejadian yang tidak diharapkan yang bertujuan untuk mengoreksi system dalam rangka miningkatkan keselamatan pasien (pasal 43, butir 1,2,4).

Kejadian Tidak Diharapkan (KTD) / adverse event adalah suatu insiden yang mengakibatkan cedera pada pasien akibat melaksanakan suatu tindakan ayau tidak mengambil tindakan yang seharusnya diambil dan bukan karena penyakit dasarnya atau kondisi pasien. Kejadian Tidak Cedera (KTC) adalah insiden yang sudah terpapar ke pasien, tetapi tidak timbul cedera. Kondisi Potensial Cedera (KPC) adalah kondisi yang sangat berpotensi untuk menimbulkan cedera, tetapi belum terjadi insiden. Kejadian sentinel adalah KTD yang mengakibatkan kematian atau cedera serius (Permenkes R.I no 1691/Menkes/Per/VIII/2001). WHO, (2014) menegmukakan fakta penting sebagai berikut: 1). Satu dari sepuluh pasien di Negara berkembang mendapat cedera selama masa perawatan di rumah sakit. 2). Dari seratus pasien yang diopname diopname di Negara maju, tujuh orang akan mengalami masalah yang disebabkan infeksi, sedangkan di negara berkembang angkanya lebih 
tinggi yaitu sepuluh dari seratus orang. Resiko kesehatan terkait infeksi di negara berkembang angkanya duapuluh kali lebih banyak disbanding di negara maju. 3). Di beberapa negara masih ada $70 \%$ yang menggunakan ulang jarum suntik tanpa disterilkan yang menyebabkan jutaan orang terinfeksi. Setiap tahun injeksi yang tidak aman menyebabkan jutaan orang terinfeksi. Setiap tahun injeksi yang tidak aman menyebabkan 1.3 juta kematian, terutama karena penularan pathogen melalui darah seperti virus hepatitis dan HIV. 4). Lebih dari 100 juta orang memerlukan tindakan bedah setiap tahun dengan alasan medis. Prosedur bedah yang tidak aman dapat mengakibatkan kematian dan cacat. 5). Sistem keamanan pada industry pesawat terbang lebih baik dibandingkan dengan layanan kesehatan. Hal ini ditunjukkan dengan besarnya peluang seorang mendapatkan musibah. Hanya 1 dari 1 juta yang berpluang mendapat musibah pada pesawat terbang, sedangkan dalam pelayanan kesehatan 1 dari 300 peluang pasien yang dirugikan karena mendapat cedera selama proses perawatan.

Gambaran di Indonesia berdasarkan Peta Nasional Insiden Keselamatan pasien didapati bahwa dari 145 insiden yang dilaporkan, ada 69 kasus (47.6\%) masuk dalam kategori KNC dan 67 kasus $(46,2 \%)$ masuk kategori KTD dan 9 kasus atau 6.2\% masuk kategori lainnya. Sedangkan apabila dilihat berdasarkan provinsi ditemukan bahwa dari 145 insiden, ada 55 kasus (37.9\%) terjadi di wilayah DKI, dan disusul Jawa Tengah sebanyak 15.9\%, Yogyakarta $13.8 \%$, Jawa Timur $11.7 \%$, Sumatra Selatan $6.9 \%$, Jawa Barat 2.8\%, Bali $1.4 \%$, Sulawesi Selatan $0.69 \%$ dan insiden terkecil terjadi di Aceh yaitu sebesar $0.68 \%$ (Kongres PERSI, 2007 dalam Mulyana, 2013).
Berdasarkan data subyektif yang penulis peroleh melalui studi wawancara terungkap fakta bahwa masih banyak insiden atau kesalahan yang telah dilakukan namun tidak dilaporkan dengan alasan takut mendapat hukuman atau dianggap tidak kompeten oleh teman sekerja. Berdasarkan temuan penting yang diungkap oleh WHO serta gambaran di Indonesia dan Rumah sakit Advent Bandarlampung mencerminkan bagaimana prilaku tenaga kesehatan dapat berdampak terhadap keselamatan pasien. Ketidakpatuhan tenaga kesehatan terhadap standar keselamatan pasien. Ketidakpatuhan tenaga kesehatan terhadap standar keselamatan merupakan gambaran tata laku budaya yang berkontribusi terhadap budaya keselamatan pasien.

Di dalam meningkatkan keselamatan pasien, hal pertama yang harus dilakukan adalah melakukan transformasi budaya karena budaya adalah dasar seseorang memaknai, bersikap, berprilaku dan bertindak. Budaya keselamatan pasien adalah seperangkat keyakinan, asumsi dan prilaku normatif yang aktif mempengaruhi bagaimana pekerja berpikir dan bertindak sehubungan dengan isu-isu keamanan (Maier, 2013). Menurut Sorra \& Nieva, (2003) ada 12 dimensi yang terkandung didalam budaya keselamatan pasien yakni: 1). Frekuensi pelaporan insiden. 2). Persepsi tentang keselamatan pasien secara menyeluruh. 3). Harapan dan tindakan manajer dalam meningkatkan keselamatan pasien. 4). Pembelajaran organisasi - perbaikan berkelanjutan. 5). Kerjasama tim dalam unit. 6). Komunikasi terbuka. 7). Umpan balik dan komunikasi tentang kesalahan. 8). Respon tidak menghukum terhadap kesalahan. 9). Staffing. 10). Dukungan manajemen rumah sakit terhadap 
program keselamatan pasien. 11). Kerjasama tim antar unit. 12). Overan dan transisi.

Perawat dan dokter mempunyai andil besar dalam meningkatkan budaya keselamatan pasien di rumah sakit. Perawat sebagai profesi tenaga kesehatan dengan jumlah paling besar diantara tenaga kesehatan lainnya dan paling lama kontak dengan pasien serta tersebar diberbagai tempat penyedia layanan kesehatan, dianggap mempunyai peran penting dalam upaya mengukur, memonitor serta memperbaiki kualitas asuhan serta keamanan pasien. Pada saat pasien diopname dengan berbagai kondisi, maka perawat adalah orang yang paling banyak menggunakan waktunya dengan pasien. Seberapa baik seorang pasien dirawat oleh perawat akan mempengaruhi kesehatan pasien. Peran perawat juga penting dalam mencegah dan menemukan kesalahan medis yang dapat menyebabkan kematian dan ancaman serius. Berdasarkan sebuah penelitian yang dilakukan terkait kesalahan dalam medikasi yang terjadi di dua rumah sakit selama lebih dari enam bulan ditemukan bahwa sebanyak $86 \%$ perawat berhasil mencegah terjadinya kesalahan medikasi yang dilakukan oleh dokter dan petugas farmasi sehingga kesalahan itu tidak sampai dialami oleh pasien (Bates, et al., 1995). Oleh karena itu maka perawat harus berupaya lebih keras untuk memberikan perawatan yang komprehensif, berbasis evidence dan berpusat pada kebutuhan pasien sehingga keselamatan pasien dirumah sakit dapat tercapai.

Mengkaji persepsi perawat dan dokter tentang budaya keselamatan pasien merupakan langkah awal yang perlu dilakukan ketika pimpinan ingin meningkatkan kualitas pelayanan dan keselamatan oleh karena prilaku seseorang dapat dipengaruhi oleh berbagai persepsinya terhadap sesuatu. Organisasi perlu mengetahui bagaimana persepsi perawat dan dokter terhadap penerapan budaya keselamatan pasien (Reason, 2002). Oleh karena itu penulis merasa perlu untuk mengukur persepsi perawat dan dokter terhadap penerapan budaya keselamatan pasien sehingga hasilnya dapat dijadikan acuan dalam melakukan perbaikan.

\section{METODE PENELITIAN}

Penelitian descriptive comparative cross sectional design tentang persepsi perawat dan dokter dilakukan kepada 130 responden dengan menggunakan instrument Hospital Survey of Patient Safety Culture (HSOPSC) yang terdiri dari 12 dimensi. Pengukuran persepsi terhadap masing-masing dimensi dilakukan untuk mengetahui dimensi mana yang masih perlu ditingkatkan. Uji statistic mann Whitney digunakan untuk mengetahui apakah terdapat perbedaan persepsi antara perawat dan dokter, antara staf pelaksana dan supervisor.

\section{HASIL PENELITIAN}

1. Karakteristik Responden.

Hasil analisis univariat terhadap 130 responden untuk mengukur persepsi perawat dan dokter terhadap penerapan budaya keselamatan budaya keselamatan pasien maka didapatkan data sebaran responden seperti yang tertera didalam tabel 1 .

Berdasarkan tabel tersebut dapat diketahui bahwa responden paling banyak adalah profesi perawat $(93.1 \%)$ dengan posisi sebagai staf pelaksana $(87.6 \%)$. 
Tabel 1. Karakteristik Responden

\begin{tabular}{|l|l|l|}
\hline Variabel & Sub variable & $\begin{array}{l}\text { Frekuensi } \\
\text { presentase }\end{array}$ \\
\hline Profesi & Perawat & $\begin{array}{c}121 \\
(93,1 \%)\end{array}$ \\
\cline { 2 - 3 } & Dokter & $9(6,9 \%)$ \\
\hline Posisi & $\begin{array}{l}\text { Staff } \\
\text { Pelaksana }\end{array}$ & $106(87,6 \%)$ \\
\cline { 2 - 3 } & Supervisor & $15(12,4 \%)$ \\
\hline
\end{tabular}

Deskripsi Persepsi Responden Terhadap 12 Dimensi Budaya Keselamatan Pasien Berdasarkan Profesi dapat dilihat pada tabel.2

Tabel.2 Persepsi Berdasarkan Profesi

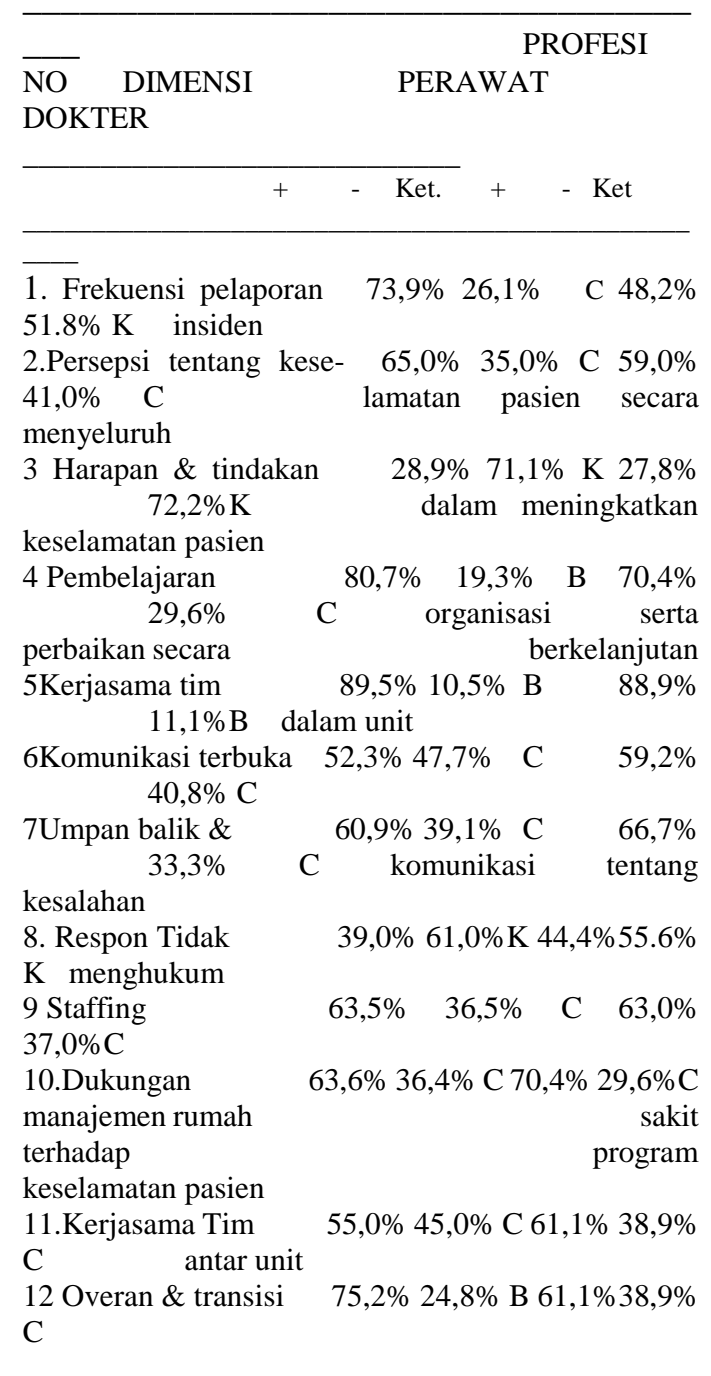

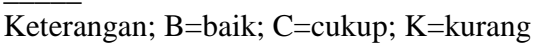

Nilai rata-rata respon positif dari 12 dimensi yang diberikan oleh perawat $(62,3 \%)$ lebih tinggi dibandingkan dengan dokter $(60,1 \%)$, namun keduanya masih dalam kategori cukup. Didalam kelompok profesi perawat, ada tiga dimensi yang masuk dalam kategori baik, tujuh dimensi dalam kategori cukup dan dua dimensi dalam kategori kurang. Sedangkan untuk profesi dokter, ada satu dimensi masuk dalam kategori baik, Sembilan dimensi dalam kategori cukup dan tiga dimensi dalam kategori kurang.

Persepsi terhadap dimensi frekuensi pelaporan insiden pada perawat lebih baik pada perawat $(73,9 \%)$ dibandingkan dengan profesi dokter $(48,2 \%)$. Persepsi tentang keselamatan pasien secara menyeluruh pada perawat (65\%) sedikit lebih tinggi dibandingkan dengan dokter $(59,0 \%)$, namun keduanya masih dalam kategori cukup. Persepsi terhadap dimensi harapan dan tindakan manajer dalam meningkatkan keselamatan pasien dalam kategori kurang, dimana pada perawat $(28,9 \%)$ dan dokter $(27,8 \%)$. Persepsi terhadap dimensi pembelajaran organisasi serta perbaikan secara berkelanjutan pada profesi perawat $(80,7 \%)$ lebih tinggi dibandingkan dengan dokter $(70,4 \%)$ namun keduanya berbeda dalam kategori, perawat dalam kategori baik, sedangkan dokter kategori cukup. Persepsi terhadap kerjasama tim dalam unit sudah dalam kategori baik dimana pada profesi dokter $(88,9 \%)$ dan profesi perawat $(89,5 \%)$. Dimensi komunikasi terbuka pada profesi perawat $(52,3 \%)$ sudah dalam kategori cukup sedangkan pada profesi dokter $(59,2 \%)$ masih dalam kategori cukup. Persepsi terhadap dimensi umpan balik 
dan komunikasi tentang kesalahan pada profesi perawat $(60,9 \%)$ sudah dalam kategori cukup sedangkan pada dokter $(55,6 \%)$ masih dalam kategori cukup.

Persepsi terhadap dimensi respon tidak menghukum terhadap kesalahan, dari profesi dokter (44.4\%) dalam kategori kurang, sedangkan pada profesi perawat lebih rendah yaitu $(39,0 \%)$ dalam kategori kurang. Persepsi terhadap dimensi staffing pada perawat $(63,5 \%)$ dan dokter $(63,0 \%)$ masih dalam kategori cukup. Persepsi terkait dimensi dukungan manajemen rumah sakit terhadap program keselamatan pasien dari profesi perawat $(63,6 \%)$ dan dokter $(61,1 \%)$ masih dalam kategori cukup. Persepsi terhadap dimensi kerjasama tim antar unit pada perawat $(55,0 \%)$ dan dokter sebesar $(61,1 \%)$ masih dalam kategori cukup. Persepsi terhadap dimensi overan dan transisi dari profesi perawat $(75,2 \%)$ dan dokter $(61,1 \%)$ juga masih dalam kategori cukup.

2. Persepsi perawat dan dokter berdasarkan posisi

Nilai rata-rata respon positif terhadap 12 dimensi yang diberikan oleh kelompok supervisor lebih tinggi dibandingkan dengan kelompok staf pelaksana, dimana pada kelompok supervisor sebesar $(64,2 \%)$ sedangkan pada staf pelaksana sebesar $(62,3 \%)$ namun keduanya masih dalam kategori cukup.

Tabel.3 Persepsi Berdasarkan Posisi

\begin{tabular}{|c|c|c|c|c|}
\hline $\mathrm{NO}$ & & $\begin{array}{l}\text { DIMENSI } \\
\text { SUPERVISOR }\end{array}$ & STAFF & $\begin{array}{l}\text { POSISI } \\
\text { PELAKSANA }\end{array}$ \\
\hline Ket & + & Ket & & + \\
\hline
\end{tabular}

1.Frekuensi pelaporan $72,3 \% 27,7 \%$ C 5,6\% $24,4 \%$ $\mathrm{B}$ insiden

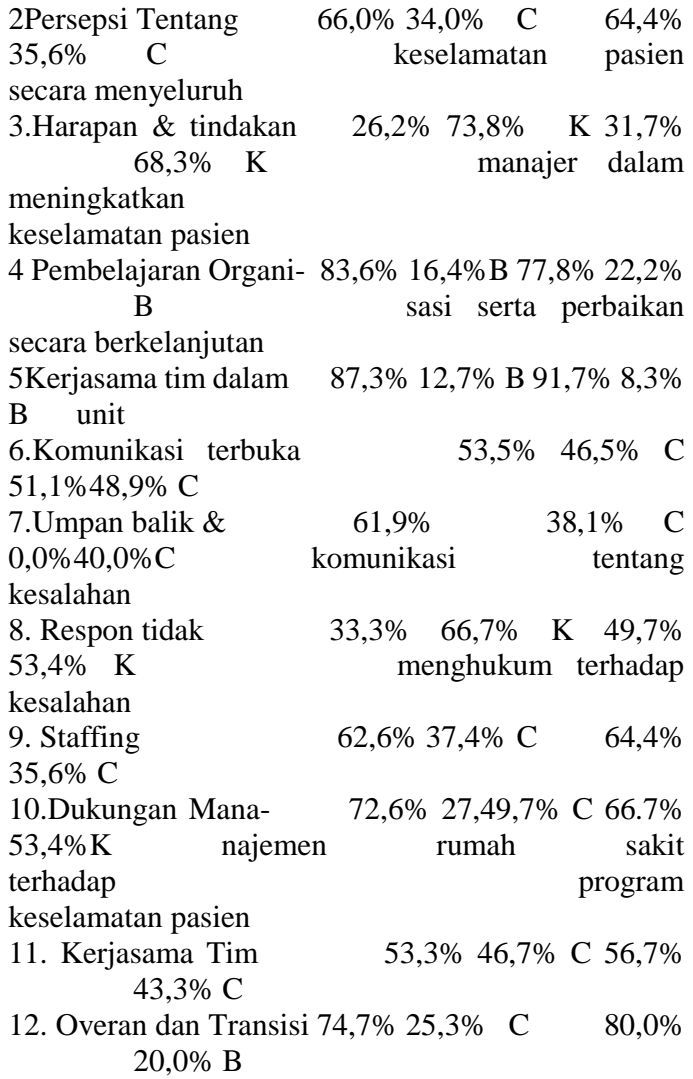

RATA-RATA

$62,3 \% 37,7 \% \quad \mathrm{C} 64,2 \%$

$35,8 \% \mathrm{C}$

keterangan; $\mathrm{B}=$ baik; $\mathrm{C}=$ cukup; $\mathrm{K}=$ kurang

Pada kelompok staf pelaksana ada dua dimensi yang masuk dalam kategori baik, delapan dimensi yang masuk dalam kategori cukup dan dua dimensi dalam kategori kurang. Sedangkan pada kelompok supervisor ada empat dimensi masuk dalam kategori baik, enam dimensi dalam kategori cukup dan dua dimensi dalam kategori kurang.

Frekuensi pelaporan insiden dari supervisor $(75,6 \%)$ lebih baik dibandingkan dengan staf pelaksana (72,3\%). Persepsi tentang keselamatan pasien secara menyeluruh pada staf pelaksana $(66,0 \%)$ dan supervisor $(64,4 \%)$ mempunyai kategori yang sama yaitu cukup. Persepsi terhadap dimensi harapan dan tindakan manajer dalam meningkatkan keselamatan pasien pada kelompok supervisor $(31,7 \%)$ lebih baik 
dibandingkan pada kelompok staf pelaksana $(26,2 \%)$ tapi masih dalam kategori kurang sehingga perlu ditingkatkan. Persepsi terhadap dimensi pembelajaran organisasi serta perbaikan secara berkelanjutan pada kedua kelompok sudah baik, namun persepsi pada kelompok staf pelaksana $(83,6 \%)$ lebih tinggi dibandingkan pada kelompok supervisor $(91,7 \%)$ lebih tinggi dibandingkan staf pelaksana $(87,3 \%)$ namun keduanya sudah dalam kategori baik. Persepsi terhadap dimensi komunikasi terbuka pada staf pelaksana $(53,5 \%)$ sedikit lebih tinggi dibandingkan kelompok supervisor $(51,1 \%)$ namun keduanya dalam kategori cukup. Persepsi tentang umpan balik dan komunikasi tentang kesalahan pada staf pelaksana $(61,9 \%)$ lebih baik dibandingkan dengan supervisor $(60 \%)$ tapi dalam kategori yang sama ialah cukup.

Persepsi tentang respon tidak menghukum terhadap kesalahan pada kelompok supervisor $(49,7 \%)$ dan staf pelaksana $(33,3 \%)$ masih dalam kategori kurang sehingga sangat perlu untuk ditingkatkan. Dimensi staffing pada supervisor $(64,4 \%)$ masih lebih tinggi dibandingkan dengan kelompok staf pelaksana $(62,6 \%)$ namun keduanya masih dalam kategori cukup. Persepsi tentang dukungan manajer rumah sakit terhadap keselamatan pasien pada kelompok supervisor $(66,7 \%)$ sudah masuk kategori cukup. Persepsi terhadap kerjasama tim antar unit pada supervisor (56,7\%) sudah dalam kategori cukup sedangkan pada staf pelaksana $(53,3 \%)$ masih dlam kategori cukup. Persepsi terhadap dimensi overran dan transisi ada perbedaan yaitu $(80 \%)$ pada supervisor dalam kategori baik dan $(74,7 \%)$ pada staf pelaksana dalam kategori cukup.
Analisis Bivariabel

1. Perbedaan Persepsi Antara perawat dan Dokter berdasarkan Profesi

Tabel.4 Perbedaan Persepsi Antara perawat dan Dokter Berdasarkan Profesi

$\overline{\text { P Value }}_{\text {Profesi Mean }}^{\substack{\text { Median } \\ \text { Deviasi }}}$ Std. Range 95\%CI

Perawat $117.55 \quad 107 \quad 25.542 \quad 46-78 \quad 112.96-122.15$ 0,787

Dokter $\quad 116.33 \quad 11326.926 \quad 55-69 \quad 95.65-$ 137.03

Nilai p value berdasarkan profesi sebesar 0.787 menunjukkan bahwa tidak terdapat perbedaan persepsi penerapan budaya keselamatan pasien antar profesi perawat dan dokter. Namun profesi perawat mempunyai nilai mean atau nilai rata-rata lebih tinggi dibandingkan profesi dokter. Hal ini menunjukkan profesi perawat mempunyai persepsi yang lebih baik terhadap penerapan budaya keselamatan pasien bila dibandingkan denagan profesi dokter.

2. Perbedaan Persepsi Antara Perawat dan Dokter Berdasarkan Posisi

Hasil yang diperoleh dalam penelitian ini adalah tidak terdapat perbedaan persepsi terhadap penerapan budaya keselamatan pasien antara staf pelaksana dengan supervisor. Hal ini berdasarkan pada nilai $\mathrm{p}$ value sebesar 0.251. Bila melihat nilai mean atau nilai rata-rata, hal ini berarti kelompok supervisor mempunyai persepsi lebih baik dibandingkan dengan kelompok staf pelaksana.

Tabel.5 Perbedaan Persepsi Berdasarkan Posisi 
Posisi Mean Median Std. Range 95\%CI P Value Deviasi

Staf Pelaksana

$116.71 \quad 107.00 \quad 25.707 \quad 46-80 \quad 111.76-121.66$ 0.848

Supervisor

$119.00 \quad 111.0026 .758 \quad 49-77 \quad 104.18-133.82$

\section{PEMBAHASAN}

Hasil penelitian ini menunjukkan perawat dan dokter mempunyai persepsi paling baik pada dimensi kerjasama tim dalam unit. Sedangkan dimensi yang mendapat persepsi paling buruk adalah harapan dan tindakan manajer dalam meningkatkan keselamatan pasien dan respon tidak menghukum terhadap kesalahan. Hasil penelitian ini hamper sama dengan hasil penelitian di berbagai tempat seperti penelitian yang dilakukan oleh I - Chi Chen dan Huang-Hui-Li, (2010) di 42 rumah sakit di Taiwan; Penelitian lain yang dilakukan oleh Sorra, J., Nieva, V., famolara, T dan Dyen, N., (2007) di 382 rumah sakit di Amerika Serikat; Penelitian yang dilakukan oleh Hellings, J et al., (2007) di 5 rumah sakit di Belgia; Penelitian di Libanon yang dilakukan oleh El-Jardali, et al (2010); Penelitian lain yang dilakukan di China kepada responden di 32 rumah sakit dari 15 kota di China.

Salah satu aspek yang perlu diukur didalam budaya keselamatan pasien adalah pelaporan insiden. Pelaporan insiden merupakan komponen penting dalam meningkatkan keselamatan pasien. Budaya pelaporan hanya bisa terjadi dilingkungan non-punitive (Smits, Christians-Dingelhoff, Wagner, Wal, \& Groenewegen, 2008). Ada beberapa alas an mengapa banyak insiden yang tidak dilaporkan, diantaranya karena merasa takut mendapat hukuman, adanya respon menghukum terhadap kesalahan yang terjadi, serta adanya fakta bahwa pelaporan tersebut biasanya tidak menghasilkan perubahan yang sebenarnya. Namun ada juga disebabkan oleh karena staf tidak menghargai aturan yang telah dibuat (VanGeest \& Cummins DS, 2003).

Didalam penelitian ini, persepsi perawat terhadap frekuensi pelaporan insiden lebih baik dibandingkan dokter, dimana persentase pada perawat 73,9\% (kategori cukup) sedangkan dokter hanya 48,2\% (kategori kurang). Hal ini sesuai dengan data yang penulis peroleh dari komite keselamatan pasien rumah sakit bahwa profesi dokter jarang melakukan pelaporan insiden. Alasan mengapa dokter enggan untuk melaporkan kesalahan adalah oleh karena mereka merasa insiden atau kesalahan tersebut tidak akan berdampak besar kepada pasien. Selain itu mereka juga takut dianggap tidak kompeten dalam melakukan pekerjaan mereka.

Heru, Halimi \& nafsiah, (2014) juga mengemukakan berbagai faktor yang menyebabkan penurunan pelaporan insiden keselamatan pasien, seperti takut disalahkan, kurang memahami mekanisme pelaporan insiden, kurang komitmen dari pihak manajemen atau unit terkait, tidak ada reward dari rumah sakit jika melaporkan serta ketidakefektifan Komite keselamatan pasien Rumah Sakit (KKP-RS). Pear, (2012) menyatakan bahwa hanya satu dari tujuh kesalahan medis yang terjadi yang akan dilaporkan.

Pada profesi perawat, kemauan untuk melaporkan insiden atau kesalahan mulai meningkat. Dalam organisasi yang mempunyai budaya keselamatan yang positif, para dokter, perawat dan seluruh yang terkait dalam layanan kesehatan melihat bahwa kesalahan atau insiden 
yang dilaporkan merupakan bagian integral dari proses pembelajaran dan peningkatan kualitas (Reason, 2000).

Dalam penelitian ini persepsi tentang keselamatan pasien secara menyeluruh pada dokter (59\%) lebih rendah dari pada perawat $(65 \%)$, namun masih sama-sama dalam kategori cukup. Hal ini mendukung hasil penelitian Kim, et al., (2005) bahwa pada umumnya dokter mempunyai persepsi negatif terhadap budaya keselamatan dan mereka juga mempunyai persepsi negative terhadap komitmen pimpinan rumah sakit dalam hal peningkatan keselamatan pasien. Baik buruknya persepsi tersebut juga merupakan tanggapan yang diberikan sebagai implikasi interaksi pengalaman yang terjadi. Budaya keselamatan organisasi membutuhkan komitmen manajemen terhadap keselamatan.

Harapan dan tindakan manajer dalam meningkatkan keselamatan pasien merupakan penilaian tentang bagaimana tindakan supervisor atau manejer dalam meningkatkan keselamatan pasien, apakah supervisor atau manajer memperhatikan saran dari staf untuk meningkatkan keselamatan pasien, memberikan pujian kepada staf yang mengikuti prosedur keselamatan pasien dan yang tidak mengabaikan masalah keselamatan pasien. Persepsi perawat dan dokter terhadap dimensi ini dalam kategori kurang, dimana pada profesi perawat sebesar $28.9 \%$ dan dokter $27.8 \%$. Ini menunjukkan bahwa baik perawat maupun dokter menganggap supervisor atau manajer kurang memperhatikan saran dari staf, kurang memberikan apresiasi kepada bawahan yang telah melakukan tindakan sesuai dengan prosedur keamanan. Dokter atau perawat akan merasa senang apabila mereka diperhatikan serta diberi apresiasi oleh atasan. Hal ini akan mendorong mereka untuk semakin terlibat dalam mendukung program keselamatan pasien. Thomas, Sexton, Neilands, Frankel \& Helmreich, (2005) menyatakan bahwa manajer perlu melakukan executive walkround yaitu mengunjungi unit pelayanan secara rutin untuk mencari tahu permasalahan yang ada di unit tersebut sambil mendengar masukan dari bawahan. Hal ini akan mempengaruhi budaya keselamatan pasien.

Untuk meningkatkan keselamatan pasien maka diperlukan budaya organisasi yang mendukung terjadinya proses belajar khususnya disaat terjadi insiden atau kesalahan. Apabila di dalam organisasi staf merasa bebas untuk mendiskusikan tentang kesalahan dan berniat untuk belajar dari kesalahan itu dengan melakukan Root Cause Analysis maka akan terjadi perubahan budaya dari budaya menyalahkan menjadi budaya yang terbuka untuk pembelajaran. Kegagalan untuk belajar dari kesalahan yang telah terjadi menyebabkan pengulangan kejadian yang sama dengan akar permasalahan yang sama (Walshe, 2002).

Di dalam penelitian ini, dimensi pembelajaran organisasi serta perbaikan berkelanjutan pada profesi perawat $(80.7 \%)$ dalam kategori baik, lebih tinggi dibandingkan dokter (70.4\%) dalam kategori cukup. Proses pembelajaran yang dilakukan di Rumah sakit Advent bandarlampung adalah dengan melakukan root cause analysis terhadap insiden yang terjadi. Hal ini dilakukan oleh tim khusus. Penanganan yang dilakukan disesuaikan dengan derajat resiko yang ditimbulkan. Biasanya individu yang melakukan kesalahan akan diminta untuk membuat makalah terkait jenis kesalahan yang dilakukan. Setelah itu individu tersebut diminta 
untuk mempresentasikan hasil makalah tersebut dihadapan rekan kerja. Melalui proses ini diharapkan staf lain akan belajar dan diingatkan kembali, sehingga diharapkan kesalahan yang sama tidak akan terulang lagi dikemudian hari.

Dalam penelitian ini persepsi tentang kerjasama tim pada profesi perawat $(89.5 \%)$ sedikit lebih tinggi dibandingkan dengan dokter (88.9\%), namun keduanya sudah dalam kategori baik. Kerjasama tim yang baik pada profesi perawat ditunjukkan dengan cara saling membantu untuk menyelesaikan tugas dan tanggungjawab dalam setiap shift. Walaupun ada pembagian tugas dan tanggungjawab, namun apabila ada seorang perawat yang membutuhkan bantuan atau sedang sibuk maka perawat yang lain didalam tim tersebut akan membantu. Tugas dan tanggungjawab itu akan diselesaikan bersama sebelum pergantian shift. Hal yang sama juga terjadi pada profesi dokter. Mereka akan saling membantu apabila ada dokter lain yang membutuhkan bantuan. Apabila seorang dokter berhalangan untuk menangani seorang pasien, maka dokter yang lain akan bersedia menggantikan dokter yang berhalangan tersebut. Kerjasama tim yang baik dapat membantu mengurangi masalah keselamatan pasien (Bower, Campbell, Bojke, \& Sibbald, 2003).

Dimensi komunikasi terbuka adalah ukuran dari kesediaan perawat atau dokter untuk berbicara ketika mereka melihat sesuatu yang tidak benar dilakukan yang dapat membahayakan keselamatan pasien. Staf merasa bebas untuk berbicara jika mereka melihat sesuatu yang mungkin memberikan dampak negatif kepada pasien dan merasa bebas bertanya kepada mereka yang mempunyai otoritas. Dalam penelitian ini persepsi perawat terhadap dimensi komunikasi terbuka dalam kategori cukup (52.3\%), sedangkan pada profesi dokter dalam kategori cukup (59.2\%). Berdasarkan hasil analisa terhadap 2455 kejadian sentinel yang dilaporkan kepada the Joint Commision for Hospital Accreditation di Amerika Serikat ternyata lebih dari $70 \%$ akar permasalahannya disebabkan oleh kegagalan dalam komunikasi (JCAHO, 2008). Oleh karena masalah komunikasi sangat penting dalam keselamatan pasien maka perlu ditingkatkan dalam profesi dokter dan perawat.

Dimensi umpan balik dan komunikasi tentang kesalahan adalah ukuran persepsi dari perawat atau dokter bahwa atasan menyampaikan informasi kepada bawahan terkait kesalahan atau insiden yang terjadi. Atasan dan bawahan membahas tentang insiden atau kesalahan yang terjadi dan menjelaskan langkah yang diperlukan untuk mencegah kejadian yang sama terulang kembali. Hasil penelitian ini menunjukkan bahwa persepsi terhadap dimensi umpan balik dan komunikasi tentang kesalahan pada perawat $(60.9 \%)$ dalam kategori cukup sedangkan pada dokter $(66.7 \%)$ dalam kategori cukup. Ini berarti bahwa perawat masih perlu ditingkatkan adanya umpan balik yang diberikan oleh atasan tentang kesalahan yang terjadi. Umpan balik yang diberikan atasan akan menolong bawahan untuk memahami perilaku seperti apa yang harus mereka lakukan untuk meningkatkan keselamatan pasien... demikian juga pada profesi dokter dimensi ini masih perlu ditingkatkan. Dokter yang mempunyai posisi sebagai supervisor atau manajer perlu meningkatkan komunikasi dan lebih sering memberikan umpan balik terkait insiden yang terjadi.

\section{HASIL}


Hasil dalam penelitian ini menunjukkan bahwa persepsi terhadap dimensi tidak menghukum terhadap kesalahan berada masih dalam kategori sangat kurang sehingga perlu untuk ditingkatkan. Berdasarkan hasil wawancara perawat mengakui bahwa ada banyak kesalahan yang mereka lakukan yang tidak disampaikan kepada kepala ruangan atau supervisor, apalagi kalau kesalahan terdebut tidak berdampak fatal bagi pasien. Alasan mereka enggan melaporkan adalah karena merasa trauma dengan masa lalu, dimana pada waktu yang lalu perlakuan yang diterima oleh perawat yang melakukan kesalahan bisa dari sekedar mendapat teguran lisan, teguran terrtulis, penurunan jabatan, membayar ganti rugi, dimutasi ke unit kerja lain bahkan ada yang sampai capoff atau tidak diijinkan menggunakan topi perawat selama menjalani masa hukuman. Hukuman seperti ini tentu saja membuat si pelaku merasa malu dan depresi. Praktek yang terjadi seperti ini selama bertahun-tahun melekat kuat dalam ingatan perawat. Demikian juga dengan profesi dokter. Dokter merasa takut apabila kesalahan yang mereka lakukan akan membuat mereka harus menerima konsekuensi negative seperti tindakan disiplin, kehilangan hak-hak yang selama ini diperoleh serta tuduhan malpraktik. Kondisi masyarakat saat ini yang sering membawa masalah yang diakibatkan kesalahan medis ke jalur hukum juga membuat dokter enggan untuk mengungkap dan melaporkan setiap kesalahan yang terjadi.

Berdasarkan posisi hasil penelitian ini didapati bahwa dari 12 dimensi yang ada skor persepsi supervisor lebih tinggi dibandingkan staf pelaksana. Supervisor member skor yang lebih tinggi terhadap dimensi yang berhubungan dengan frekuensi pelaporan insiden (76.6\%) sedangkan pada staf pelaksana masih dalam kategori cukup (72.3\%). Kerjasama tim dalam unit pada staf pelaksana (87.3\%) sedangkan supervisor $(91.7 \%)$ keduanya dalam kategori baik. Demikian juga pada dimensi overran dan transisi pada staf pelaksan (74.7\%) masih dalam kategori cukup sedangkan supervisor $(80.0 \%)$ dalam kategori baik. Untuk dimensi respon tidak menghukum terhadap kesalahan juga terdapat perbedaan skor, untuk supervisor (49.7\%) sedangkan staf pelaksana (33.3\%) keduanya dalam kategori kurang. Hasil diatas menunjukkan staf pelaksana mempunyai ketakutan lebih besar terhadap hukuman akibat melakukan kesalahan ketimbang supervisor. Hal ini bisa jadi disebabkan oleh karena ada perbedaan tugas dan tanggungjawab anrata staf pelaksana dengan pimpinan. Staf pelaksana yang terjun langsung ke pasien melihat dari dekat permasalahan pasien, dituntut bekerja sesuai dengan parameter yang telah ditetapkan. Sebagai pelaksana mereka dituntut untuk melakukan praktek yang aman. Sementara supervisor lebih banyak melakukan urusan manajerial dan tidak banyak kontak langsung dengan pasien. Secara administrasi supervisor akan menerima semua laporan insiden dari staf pelaksana dan meneruskannya ke tingkat yang lebih tinggi. Tentu saja staf pelaksana yang lebih banyak melaksanakan pelayanan kepada pasien mempunyai resiko lebih besar untuk melakukan kesalahan ketimbang supervisor.

Berdasarkan analisis bivariat perbedaan persepsi berdasarkan profesi didapatkan hasil bahwa tidak terdapat perbedaan persepsi tentang penerapan budaya keselamatan pasien diantara profesi perawat dan dokter. Bila dilihat berdasarkan nilai rata-rata maka profesi perawat mempunyai persepsi tentang 
keselamatan pasien yang lebih baik daripada profesi dokter.

Berdasarkan analisa bivariat terhadap perbedaan persepsi berdasarkan posisi ditemukan bahwa tidak terdapat perbedaan persepsi tentang penerapan budaya keselamatan pasien antara supervisor dengan staf pelaksana. Namun bila melihat rata-rata didapati bahwa responden yang punya posisi sebagai supervisor mempunyai persepsi sedikit lebih baik tentang keselamatan pasien dibandingkan staf pelaksana.

Hasil ini hampir sama dengan hasil penelitian yang dilakukan oleh Nardin, A., Theander, K, Wilde-Larsson, B., Noerthstrom, (2013) dimana terdapat perbedaan persepsi antara manajer dengan staf pelaksana. Hasil penelitian menunjukkan bahwa skor pada manajer lebih tinggi dibandingkan dengan staf pelaksana. Dari penelitian yang dilakukan oleh Singer, et al., (2008) didapatkan hasil bahwa manager senior merasakan iklim keselamatan pasien lebih positif dibandingkan non-senior manajer pada umumnya. Peran pemimpin sangat penting dalam mendukung program keselamatan pasien. Terdapat hubungan yang erat antara kepemimpinan efektif head nurse dengan penerapan budaya keselamatan pasien (Setiowati, Allenidekania, \& sabri, 2013).

\section{KESIMPULAN}

Tidak terdapat perbedaan persepsi penerapan budaya keselamatan pasien antar profesi perawat dan dokter.

Tidak terdapat perbedaan persepsi tentang penerapan budaya keselamatan pasien antara staf pelaksana dengan supervisor.

\section{DAFTAR PUSTAKA}

Undang Undang Republik Indonesia no 29 tahun 2004 tentang Praktik Kedokteran

Undang Undang Republik Indonesia no 44 tahun 2009 tentang rumah sakit

Bates DWI, Boyle DL, Vander Vliet MB, Schneider J, Leape L. Relationship Between Medication Errors and Adverse Drug Event. J Gen Intern Med. 1995 Apr;10(4):199-205. s.

Bower, P., Campbell, S., Bojke, C., \& Sibbald, B. (2003). Team Structure, Team Climate and the Quality of Care in Primary Care. An Observational Study. Quality and Safety in Health care, 273279.

Charles, K, McKee, L., \& McCann, S. (2011, April 16). A Quest for Patient Safety Culture: Contextual Influences on Pation safety Performance. J Health Serv Res Policy, 57-64

El-jardali, F., Dimassi, H., D., Jaafar, M., \& Hemadeh, N. (2011). Predictors and Outcomes of Patient Safety Culture in Hospital. BMC Health Services Research,9

Hellings, et al. Challenging patient safety Culture: Survey Results. Int. J. Health Core Qual Assor, 2007, 20 (7) 620-32

Heru, I., halimi, M., \& Nafisah. (2014). Factors Influencing Low Hospital patient safety Insident Reporting, Jurnal Kedokteran Brawijaya.

I-Chi Chen and Huang - Liui-Li. Measuring Patient Safety Culture 
in Taiwan using HSOPSC. BMC Health Serv, June 7, 2010, Vol 10: 152

JCAHO. (2008). Improving hand-off Communication. www.jcipatientsafety.org.

Kane, Robert, L., Shamliyan, T., Mueller, C., Duval \& Wilt T.J Nurse Staffing and Quality of Patient Care: Evidence Report/Technology Assessment, no 151. Prepared for Agency for Healthcare Research and Quality (AHRO). Rockville, MD: march, 2007; Pub no 07E005;p.6.http://www.ncbl.nlm.nih .gov/pubmed/1776420

Kim, Minah Kang, Kim, Jeong Eun, An, Kyung Eh, Kim Yoan, Kim, Suk Wa. Physician's Perception of and Attitudes Towards Patient Safety Culture and Medical Error Reporting. Journal Health policy and management. Vol 15:4, 2005, pp.110-135

Mulyana, D. S. (2013). Analisis Penyebab Insiden Keselamatan Pasien oleh Perawat di Unit Rawat inap Rumah Sakit X Jakarta. Universitas Indonesia,3

Maier, K. (2013) developing A Safety Culture in the healthcare workplace.UL.LLC

Nordin, A., theander, Kersti, WildeLarsson, BH., Nordstrom. Healthjcare Staff's Perception of Patient Safety Culture in Hospital Settings and Factors of Importance for This. Open Journal of Nursing, 2013,3,28

40.http:/dx.doi.org/10.4236/ojn.20

13 Permenkes R.I no
1691/Menkes/Per/VIII/2001.

(n.d). Tentang Keselamatan pasien

Rumah Sakit

Reason, J. (2000). Human Error. Models and management. BMJ

Setiowati, D., Allenidekania, \& Sabri, L (2013). Kepemimpinan Efektif Head Nurse Meningkatkan Penerapan Budaya Keselamatan Pasien oleh Perawat Pelaksana di RSUPN Dr. Cipto mangunkusumo Jakarta, Makara Seri Kesehatan, 17(2), 55-66 Singer, Sara, Falwell, Alyson, Gaba,

David, M., et al. (2008). Patient safety Climate in US Hospitals: Variation by Management Level. Medical Care.

Sorra, J., Famolaro, T., Dyer, N. Hospital Survey on Patient Safety Culture; 2007 Comparatif databes Report. Ahrq.

Thomas, E., Sexton, J., neilands, T., Frankel, A., \& Helmreich, R. (2005). The effect of Executive Walk Rounds on Nurse Safety Climate Attitute: A randomized Trial of Clinical Units. BMC Health Serv Res

VanGeest. J., \& Cummins DS. (2003). An Educational Needs Assessment for Improving Patient Safety: Results of national Study of Phycisian and Nurses National Patient Safety Foundation. White paper Report 3.

Walshe, K. (2002). The Use and Impact of Inquiries in the NHS. BMJ

WHO. (2014) 10 Facts on Patient safety 